\title{
THE NEED FOR NUTRITIONAL JUSTICE: ASSESSING GOVERNMENT RATIONS TO LOW INCOME COMMUNITIES DURING THE COVID-19 CRISIS IN NEW DELHI
}

\author{
Riya Agrawal \\ Delhi Public School, R. K. Puram, New Delhi \\ DOI: 10.46609/IJSSER.2020.v05i07.015 URL: https://doi.org/10.46609/IJSSER.2020.v05i07.015
}

\begin{abstract}
Nutritional justice is not merely sustenance, but the enjoyment of food with the basic nutritional quality required for the healthy functioning of the human body. Over the course of the devastating COVID-19 pandemic, food security and nutritional justice has faced a threat due to the collapse of supply chains and food systems caused by systemic inequities and increased privatization. In India, the Central and State governments have largely sought to remedy the lack of access to food through distributing basic supplies through ration schemes. However, data has shown that the implementation of these schemes have been fraught with issues that prevent nutritional justice from being achieved. This paper will shed light on these schemes for low income communities and critically evaluate the successes and failures of the Indian and New Delhi state governments. The paper will then pose policy recommendations and best practices for improved implementation for the future of sustainable nutritional justice.
\end{abstract}

Keywords: Nutritional justice, Government rations, Covid-19 Crisis, Nutritional quality, Food system

\section{INTRODUCTION}

The COVID-19 pandemic has brought the world to a standstill through social distancing, quarantine and lockdown laws being imposed across the world. This has hit low income communities and developing countries the hardest, due to the fact that access to food and resources in these countries was already strained before the advent of the pandemic (Forsythe et al, 2020). According to World Bank estimates, the global impacts will be profound and longlasting (World Bank, 2020). For developing countries with much larger populations at risk, fewer resources, and less capacity, the pressure to develop innovative approaches, test them quickly, and deliver them at scale is especially great (World Bank, 2020). 


\section{International Journal of Social Science and Economic Research}

ISSN: $2455-8834$

Volume: 05, Issue: 07 "July 2020"

Nutrition is of great importance on a national scale, and is directly linked to growth and economic productivity. Experts around the world recognize that investing in the delivery of nutrients has tremendous benefits (Govt of Canada, 2020). It is estimated that every dollar spent on nutrition for a child sees an average return of $\$ 30$ over their adult life. Through global nutrition investments children will live longer, healthier lives and contribute to the development of their countries (Govt of Canada, 2020).

In times of crisis, the very foundations of the food system and nutritional justice are threatened and are often disproportionately felt by women and minority communities. However, it is pertinent to note that nutritional justice in most countries has not been fulfilled even before the advent of the pandemic. The systemic and structural inequities which are often gendered, have served only to aggravate the impacts of the crisis (Forsythe et al, 2020; FIAN International, 2020). The causes and the factors that aggravate the impacts of the COVID-19 pandemic are closely linked to several structural causes of hunger and malnutrition. These have been denounced by civil society, including social movements, grassroots organizations and CSOs (FIAN International, 2020).

This paper will elaborate upon the concept of nutritional justice in developing countries and examine the impacts on the same in the time of COVID-19. The paper will examine food system related policies and rationing in India, with a focus on New Delhi. Upon critically analyzing the same, the paper will conclude with policy recommendations to achieve nutritional justice in a sustainable manner, and to achieve the requisite measures required to adequately compensate minority and poorer communities who are worst affected by the pandemic.

\section{BACKGROUND}

'Nutritional justice', otherwise also known as 'food justice', has been in several countries a grassroots initiative emerging from communities in response to food insecurity and economic pressures that prevent access to healthy, nutritious, and culturally appropriate foods (food should fit the cultural background of the people consuming it) (Alkon and Agyeman, 2011). It includes more broad policy movements, such as the Food and Agricultural Organization of the United Nations (FAO, 2007). Food justice recognizes the food system as "a racial project and problematizes the influence of race and class on the production, distribution and consumption of food". This encompasses farm labor work, land disputes, issues of status and class, environmental justice, public politics, and advocacy (Alkon and Agyeman, 2011).

In India, the COVID-19 related lockdowns began in the second week of March 2020, extending in many states in different iterations till the present day, depending on factors such as death tolls, recovery rates, and incidences of the infection in each area. This has especially affected the rural 


\section{International Journal of Social Science and Economic Research}

ISSN: $2455-8834$

Volume: 05, Issue: 07 "July 2020"

and urban poor, especially the large population of migrant workers who had lost their employment and were stuck in cities far from their homes, often forced to walk long distances (UN India, 2020). The secondary impacts of the COVID-19 crisis are aggravating the challenges faced by many families, especially in terms of access to affordable and nutritious food. This could reverse some of the recent gains in reducing malnutrition (UN India, 2020). There exist schemes in place for food distribution in India, such as the Targeted Public Distribution System (TPDS), the Mid-Day meals (MDM) and the Integrated Child Development Services (ICDS), all covered under the National Food Security (NFS) Act, 2013 (UN India, 2020). Furthermore, in March 2018, the Prime Minister launched POSHAN Abhiyaan, an ambitious, multi-sectoral programme with the vision to attain a malnutrition-free India by 2022 (UN India, 2020).

In response to the pandemic, the MoHFW issued detailed guidance to ensure continued delivery of essential nutritional services during the crisis (UN India, 2020). In addition, several state governments have also issued operational guidance for delivery of lifesaving nutrition interventions including distribution of food, micronutrient supplementation, continued breastfeeding and treatment of malnourished children in the context of COVID-19 (UN India, 2020). These interventions, both at the national and state level, provide a strong basis to strengthen access to food, health and nutrition services during these times (UN India, 2020). Likewise, changes have been brought about in the TPDS scheme which include provision of $5 \mathrm{~kg}$ of rice or wheat, per person, per month for 3 months, $1 \mathrm{~kg}$ of pulses per household, per month and at home delivery of food rations to vulnerable populations - all free of cost (UN India, 2020).

However, there has been criticism in relation to the adequacy of these measures, as well as several practical challenges which have weakened their implementation and failing to meet the objective of nutritional justice. In New Delhi, the national capital, the Arvind Kejriwal government has been giving free ration, who are not registered under PDS. It has issued 50 lakh e-coupons for free ration to non-PDS beneficiaries (Sultan, 2020). To handover a fixed quota of free wheat and rice, 600 municipal and government schools have been converted into temporary delivery centres, where teachers have the responsibility to distribute food grains (Sultan, 2020). However, implementation issues such as staff crunches and non-availability of labourers due to migration has posed a challenge for the Food and Civil supplies (F\&S) department, which is preparing for second round of ration distribution to non-ration card holders (Sultan, 2020). Officials said that the exodus of labourers from national capital during lockdown was impacting supply of ration to distribution centres, which was leading to chaos and manhandling of its staff by beneficiaries (Sultan, 2020). 


\section{International Journal of Social Science and Economic Research}

ISSN: $2455-8834$

Volume: 05, Issue: 07 "July 2020"

A survey of 11,159 migrant workers stranded in various States found that between April 8 and April 13, more than 90\% did not receive rations from the government (The Hindu, 2020). In Delhi, $66 \%$ of workers and the poor surveyed stated that they did not receive cooked food from the government or other organisations (The Hindu, 2020). Other food security programs have also been impacted - for example, food security programs for children in India have been affected due to the lockdown (Suri, 2020). The ICDS provides supplementary nutrition to children upto 3 to 6 years coming to the anganwadi centers and take home rations to children less than three years and pregnant and lactating mothers, which covers a part of their daily recommended allowance (Suri, 2020). However, amidst lockdown the hot cooked meal being provided to children at the anganwadi center has been stalled (Suri, 2020). The following section of this paper will further analyze the case study of Delhi, and the efficacy of food security measures that have been attempted.

\section{DISCUSSION}

The Indian government implemented a system of red, orange and green zones depending on the number of active COVID-19 cases. States have been allowed complete discretion in classifying zones into the above categories. In Delhi, the Chief Minister Arvind Kejriwal promised an additional measure to cover an additional 30 lakh poor residents in the capital who do not have ration cards till the time they continue to reel under the economic impact of the global pandemic (Bedi, 2020). The announcement took the total number of beneficiaries under the free ration scheme to 1 crore-- almost half of the city's total population (Bedi, 2020). It was further announced that announced that MLAs and MPs in the national capital would get 2,000 food coupons each to distribute to the poor who have no documents at all (Bedi, 2020). However, there has been a significant delay in the implementation due to the backlog created by the first ration scheme (Bedi, 2020).

Aside from problems relating to implementation, the contents of government rations in terms of both the quantity and quality of foods have also come under scrutiny. Under the aforementioned scheme, each coupon will fetch a beneficiary $4 \mathrm{~kg}$ of rice, $1 \mathrm{~kg}$ of wheat and additional kits containing $1 \mathrm{~kg}$ refined oil, $1 \mathrm{~kg}$ chhole chana, $1 \mathrm{~kg}$ sugar, $1 \mathrm{~kg}$ salt, $200 \mathrm{gm}$ haldi powder, 200 gm dhania powder, 200gm chilli powder and two soap bars (65-70gms) (Bedi, 2020). Food activists have critiqued such amounts based on the inadequacy of the amounts of pulses (Roy et al, 2020). The ration scheme of the central government has also been criticized on the same grounds, on the basis that the pulses allocation is likely inadequate, given per month consumption is 4-5 kg (Roy et al, 2020). A survey conducted in Delhi revealed that rations were not being distributed fully (Bhatnagar, 2020). It said of the 15 shops which were open and distributing grains, only 13 were found to be distributing the additional kit containing oil, chole, 


\section{International Journal of Social Science and Economic Research}

ISSN: $2455-8834$

Volume: 05, Issue: 07 "July 2020"

sugar, salt, soap and masalas; while one shop in Munirka was distributing less than the stipulated quantity of food grains on priority category ration cards (Bhatnagar, 2020).

In addition, ration schemes in Delhi and across the country have been criticized on the basis that they do not account for the disproportionate effects of coronavirus on the nutrition and health of members of low-income communities (Bhatnagar, 2020; Pothan, 2020). For example, the application process for the e-coupon ration system in New Delhi requires a person to have access to a working smart phone with a valid sim and the ability to navigate an online application procedure which requires an OTP (Bhatnagar, 2020). In addition, the system requires an applicant to upload the photo of their aadhaar card and of all members of the household. This puts the system out of reach for the poorest and the most marginalised who are surviving extremely precariously and urgently require rations (Bhatnagar, 2020). Further, there has been criticism not only in Delhi but in other states, that containment measures have resulted in favoring supermarkets and industrial/processed food over other sources of food provision, including food markets, grocery stores, and informal food vendors (FIAN International, 2020). This has further alienated poorer and marginalized communities from food systems.

\section{CONCLUSION}

It is therefore clear that nutritional justice must be achieved in a more sustainable and inclusive manner. COVID-19 has created high transaction costs and uncertainty in India's transformed food supply chains, putting food security at risk as $92 \%$ of food consumption in India is purchased, predominantly from the private sector (Reardon et al, 2020). Government faces the challenge of marshalling resources between mitigating the impending food crisis and containing the contagion as the risk of sociopolitical tensions looms large (Reardon et al, 2020). It is recommended that the government concentrate on sustaining the food supply chains towards eventual rebound, recognising that government food distribution cannot replace even a tenth of the market (Reardon et al, 2020).

The food kit system implemented by Kerala was praised as being a more comprehensive and nutritionally just scheme for distribution. The government of Kerala initiated the distribution of food kits consisting of 17 items as worth INR 1000 (USD 13), starting on 8 April for every household, irrespective of income status (Pothan, 2020). One key positive measure was to protect food security in the state was setting up of community kitchens all over the state. It was the first move to provide cooked food for the needy (Pothan, 2020). District administrators were given the duty to monitor the food assistance program whereas the local representatives took responsibility in distribution and logistics (Pothan, 2020). To ensure nutritious meals for children under the age of 6, the government has instructed Anganwadi centres in the state to deliver free mid-day meals to the children registered under the Integrated Child Development Services 
International Journal of Social Science and Economic Research

ISSN: $2455-8834$

Volume: 05, Issue: 07 "July 2020"

(ICDS) (Pothan, 2020). As per the orders from the Women and Child Development Department of the state, the Anganwadi teachers are delivering raw materials on a weekly basis to the families (Pothan, 2020).

The success that Kerala has had in its implementation of food ration schemes has shown that there is a dire need to shift to discourse with new vocabulary of nutritional justice, which moves beyond mere sustenance. In order to do so, it is essential that India and other countries realize the systemic causes of such a strain on the food system in times of crisis, especially realizing the gendered impact (FIAN International, 2020; Forsythe et al, 2020). Food quality, not just quantity, must be maintained (Roy et al, 2020). India's supply chain must gear up to deal with the transportation, storage, and distribution of large volumes of food in short time frames during the lockdown to avoid spoilage and contamination (Roy et al, 2020). For future implementation to be more effective, it is important to safeguard the rights of the poor and migrant workers, and to put in place mechanisms to monitor the impacts of the COVID-19 pandemic and the measures taken to contain it on the right to food and nutrition. Information should be disaggregated by gender, socio-economic status, age and other relevant criteria, and should include testimonies by grassroots communities and affected groups (FIAN International, 2020).

\section{REFERENCES}

Alkon AH, Agyeman J (2011). Cultivating Food Justice: Race, Class, and Sustainability. Cambridge, Massachusetts: MIT Press.

Bedi, A, (1 May 2020), 'Delhi govt's food coupon scheme for poor yet to kick off, AAP MLAs say process is tedious', The Print, https://theprint.in/india/delhi-govts-food-couponscheme-for-poor-yet-to-kick-off-aap-mlas-say-process-is-tedious/412652/

Bhatnagar, GV, (2 May 2020), 'Delhi: Survey Reveals Only 30\% Ration Shops Distributing PDS Grains, Special Kits, The Wire, https://thewire.in/rights/delhi-survey-pds-ration-shops

FIAN International, (April 2020), 'Impact of COVID-19 on the Human Right to Food and Nutrition Preliminary monitoring report', https://www.fian.org/files/files/Preliminary_monitoring_report_Impact_of_COVID19_on_the_HRtFN.pdf

Food and Agricultural Organization of the United Nations, (2007), Right to Food Unit. Right to Food Questions and Answers. 
International Journal of Social Science and Economic Research

ISSN: 2455-8834

Volume: 05, Issue: 07 "July 2020"

Forsythe, L, et al, (2020), 'Impacts of COVID-19 on food systems: the gender and inequalities perspective', Natural Resources Institute, https://www.nri.org/latest/news/2020/impactsof-covid-19-on-food-systems-the-gender-and-inequalities-perspective

Government of Canada, (2020), 'Nutrition in Developing Countries', https://www.international.gc.ca/world-monde/issues_developmentenjeux_developpement/global_health-sante_mondiale/nutrition.aspx?lang=eng

Pothan, PE, (22 April 2020), 'Local food systems and COVID-19; A glimpse on India's responses', Food and Agriculture Organization of the United Nations, http://www.fao.org/in-action/food-for-cities-programme/news/detail/en/c/1272232/

Reardon, T, et al, (2 May 2020), 'COVID-19's Disruption of India's Transformed Food Supply Chains', EPW, Vol.55, Issue 18

Roy, D, et al, (6 April 2020), 'How India's food-based safety net is responding to the COVID-19 lockdown', IFPRI Blog, https://www.ifpri.org/blog/how-indias-food-based-safety-netresponding-covid-19-lockdown

Sultan, P, (16 May 2020), 'Distribution of ration in Delhi hit by migrant labour shortage due to COVID-19 crisis', The New Indian Express, https://www.newindianexpress.com/cities/delhi/2020/may/16/distribution-of-ration-indelhi-hit-by-migrant-labour-shortage-due-to-covid-19-crisis-2144033.html

Suri, S, (20 April 2020), 'Food security for children amidst Covid19: A cause for concern', ORF Health Express, https://www.orfonline.org/expert-speak/food-security-for-childrenamidst-covid19-a-cause-for-concern-64877/

The Hindu Data Team, (27 April 2020), 'Data | 96\% migrant workers did not get rations from the government, $90 \%$ did not receive wages during lockdown: survey', The Hindu, https://www.thehindu.com/data/data-96-migrant-workers-did-not-get-rations-from-thegovernment-90-did-not-receive-wages-during-lockdown-survey/article31384413.ece

UN India, (11 June 2020), 'Nutrition In The Context Of The COVID-19 Pandemic In India', https://in.one.un.org/nutrition-in-the-context-of-the-covid-19-pandemic-in-india/

World Bank, (28 May 2020), 'Food Security and COVID-19', https://www.worldbank.org/en/topic/agriculture/brief/food-security-and-covid-19 